\title{
Det gode legeliv på Frøya
}

\author{
Frøya var kledd i sin vakreste vinterdrakt da Steven Crozier og kona Eli besøkte øya første \\ gang i 1985. Folk gikk på ski overalt i havgapet. Værgudene klarte på den måten å lokke den \\ unge legefamilien til å si ja til kommunelegejobb der. 28 år senere er de fortsatt ryggraden \\ i kommunens legetjeneste.
}

Steven tar imot i nybygde, rommelige lokaler. Det er nesten så det lukter dollarikke av Steven, men av kommunens raushet med det flotte legekontoret. Så er da også Frøya en rik kommune, takket være driftige lakseoppdrettere. Steven er på tross av sin amerikanske bakgrunn betydelig fornorsket, det er nesten bare navnet som gir et hint om fødelandet.

- At flotte skiforhold bidro til at vi valgte å bosette oss her, er jo litt komisk. Så langt til havs er det jo de milde vintrene som dominerer, sier han lattermildt. - Vi har ikke hatt så mange flotte skidager på øya, men den vakre naturen er en av hovedgrunnene til at vi er blitt boende. Det rike kulturlivet og det at ungene kunne gå på videregående skole her, var også avgjørende for at vi ble. Her på øya bor det folk som vil og kan noe. Dette merker vi, og det smitter faktisk over på oss.

Ønsket om å bli allmennlege kom tidlig hos Steven. Da han var ti år, bodde familien i Tyskland. Der fikk han kusma. Det kunne ikke huslegen gjøre stort med, men det gjorde et uutslettelig inntrykk på Steven at legen ga seg tid til å høre på ham og bry seg om hans bekymringer.

- Jeg husker godt at jeg tenkte: Slik lege vil jeg bli. Da var valget om å bli allmennlege på mange måter tatt. Dr. Oppermann i Göttingen lærte meg viktigheten av å bry seg om det som rører seg i pasientens liv, at vi må bruke tid på å se pasienten som et helt menneske. Det tar ikke så mye tid. Du rekker mye på 20 minutter bare du har det rette utgangspunktet, sier han og legger til: - Det er en klar fordel å like å prate med folk hvis man skal være lege.

\section{Å se seg tilbake}

Steven er nå $i$ en alder da man ser seg tilbake. Barna har flyttet hjemmefra, andre karriereveier er uaktuelle. Det er naturlig å spørre: - Hvordan har legelivet vært?
- For meg er det naturlig å legge vekt på de gledene yrket gir meg. Allmennlegejobben er godt betalt omsorgsarbeid, kort og godt. Â få innsikt i hvordan pasientene har det $i$ livet er grunnpilaren i allmennmedisinen. Vi må spille på de positive livsopplevelsene pasientene har når vi skal engasjere oss i problemene de bringer til oss. Får vi til å flire i lag, tar jeg det som bevis på at dialogen er vellykket - å dele humor skaper tillit mellom lege og pasient.

Her på Frøya er båtlivet naturlig nok svært viktig. Å dele interesser med dem som bor her, gir meg mye glede. Bare det

\section{« få innsikt i hvordan pasientene har det i livet er grunnpilaren i allmennmedisinen»}

å voere på sjøen er herlig, sier han og føyer til: - Det er rart å høre eldre fiskere fortelle at de blir mer redd for sjøen med årene. De har opplevd situasjoner som har vist dem hvor farlig den kan være.

- Kanskje har vi eldre leger det på samme måte? undrer jeg.

- Nei, slik har ikke jeg det, svarer Steven, - jeg føler meg tryggere nå enn før. Alle erfaringene jeg har med meg etter mange år som allmennlege langt fra sykehus gjør at jeg føler meg bedre rustet til å takle de utfordringene som dukker opp.

Steven har mange utenomfaglige prosjekter - filmklubb, nærradio, privatflyging, fløytespilling og kajakkpadling er bare noe av det han har engasjert seg i parallelt med legejobben. Nylig fikk han torskeruser som en pasient hadde laget til ham - «Det må du ha, Crozier, når du bor på Frøya».

- Jeg tror at det å ha prosjekter utenom jobben forebygger utbrenthet. Det gir overskudd selv om det også forutsetter overskudd. Altså må man begynne med slikt før man er på tur inn i utbrentheten, slår han fast.

- Men legelivet byr vel ikke bare på gleder, vi blir slitne innimellom. Hva gjør du for å redusere belastningene?

- Jeg har valgt å styre timeboken min selv. På den måten kan jeg velge hvor mange «tunge» konsultasjoner jeg skal ha per dag. I tillegg spiller jeg ofte musikk under konsultasjonene, for eksempel når jeg skriver journalnotater. Da lar jeg pasienten velge musikken. Jeg husker en pensjonert fisker som spurte om jeg hadde «noe med De tre tenorer». Da jeg spilte det for ham, rant tårene nedover kinnene hans. «Det er så utrolig vakkert,» sa han. Sammen delte vi et hellig øyeblikk der og da.

Pasientene kan neppe være i tvil om at musikk inngår i fastlegetilbudet hos Steven. På hans rommelige kontor står det to store høyttalere og et voksent musikkanlegg. - Papirarbeidet går så utrolig mye lettere når jeg spiller musikk, sier han.

- Et annet grep for ikke å bli sliten er at jeg er ganske klar på hva jeg kan hjelpe pasientene med. Hvis jeg skulle løse alle problemer de kommer med, ville jeg blitt spist opp ganske fort. «Dette må du ta opp med Nav,» sier jeg, i stedet for å ringe og spørre Nav for dem.

Jeg tar meg tid til å ta unna papirarbeidet før det vokser over hodet på meg. Suget man kjenner når bunkene hoper seg opp, er verre enn papirarbeidet i seg selv.

Livet som skjærgårdslege på Trøndelagskysten har neppe bare vært enkelt, bygdedyret finner næring her som andre steder. Steven forteller at han tidlig i karrieren opplevde at lokalavisen hadde fylt halve for- 


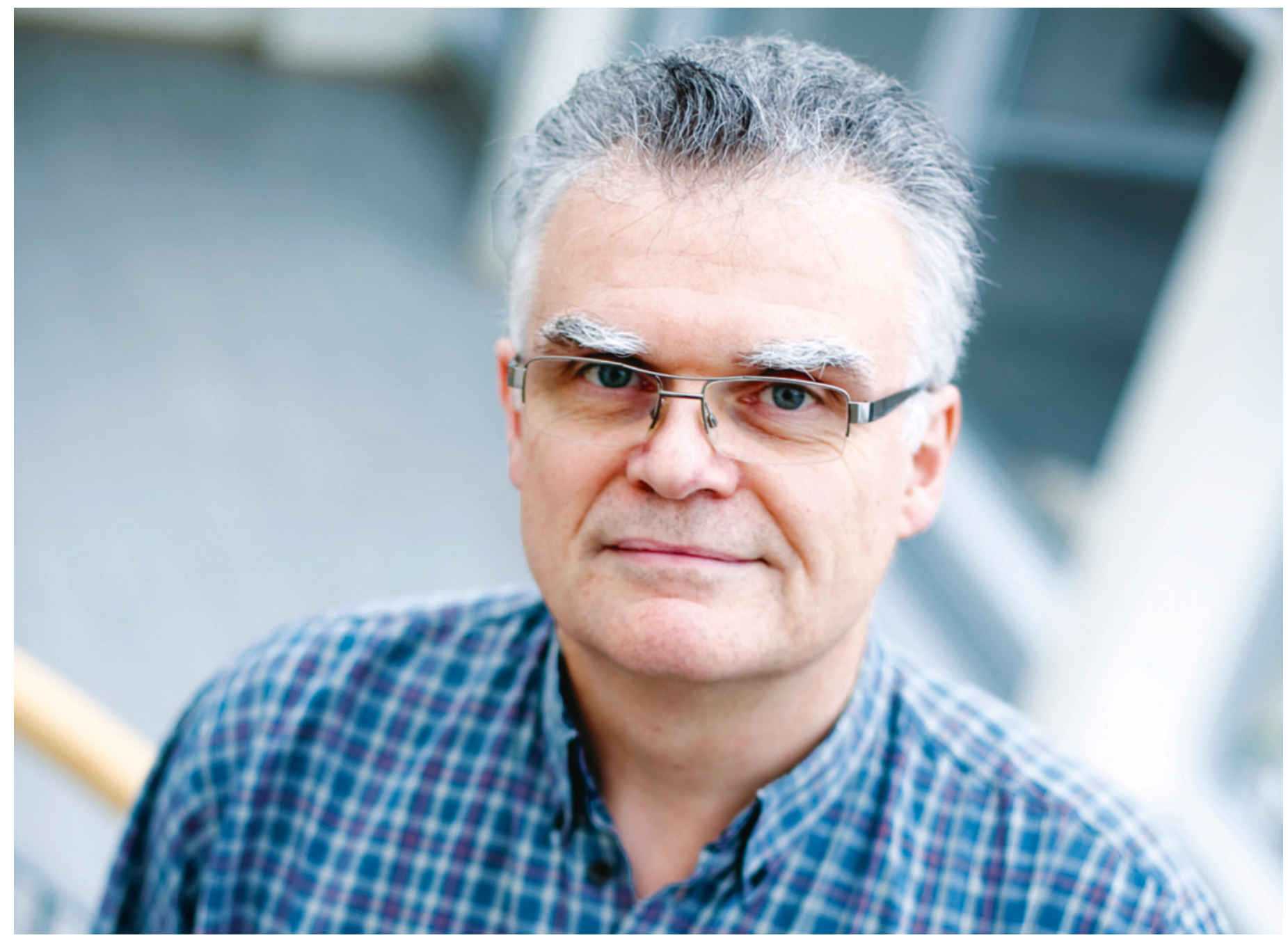

Foto Drea Utvik Karlsen

\section{Steven Richard Crozier}

Født 15.6. 1954 i Portland, Oregon, USA

- Gift, fire voksne barn

- Cand.med. Universitetet i Oslo 1982

- Spesialist i allmennmedisin 1991

- Kommunelege på Frøya fra 1985

- Nå fastlege, skole-/helsestasjonslege og smittervern-/kommuneoverlege på Frøya

- Nevrofeedbacktrener fra 2003 siden med bilde av ham med svart kant rundt og teksten: «Fikk ikke behandling, pasienten døde.» - $\AA$ bli hengt ut i avisen på den måten var svært ubehagelig. Jeg måtte jo bare leve med dette, selv om jeg tolket situasjonen annerledes enn de som hadde valgt å gå til avisen med saken.

- Å leve i et lite samfunn der man som lege treffer pasientene sine i nær sagt alle private sammenhenger, hvordan har dere taklet den utfordringen?

- Helt fra vi kom hit, har vi forsøkt å skille mellom jobb og fritid. Vi er tydelige på at rollen som lege har vi på kontoret og når vi har vakt. Øyværingene var vant til at legene var her kort tid og «arbeidet støtt». Vi visste at hvis vi skulle leve og bo her over tid, måtte vi også ha et liv utenom jobben, derfor valgte vi å engasjere oss i ulike fritidsaktiviteter. Frøyværingene har lært oss å kjenne som annet enn «legene». Av og til har vi nok tenkt at det hadde vært greit ikke å vite så mye om dem vi omgås privat, men nytten av kjennskap til pasientene over tid overgår utfordringen på fritiden. Og så kan vi jo rømme til hytta i Meldal eller dra til byen når vi har behov for avstand.

\section{Å leve med feil}

- Alle leger må avklare med seg selv at de vil komme til å gjøre feil, av og til med store konsekvenser for pasientene. Hvilke tanker har du gjort deg om dette?

- Jeg tenker enkelt: Jeg prøver å gjøre så godt jeg kan der og da, og det er faktisk godt nok. Jobben jeg gjør, blir aldri perfekt. Hvis jeg skulle fulgt alle retningslinjer til enhver tid, ville listen min blitt veldig liten. For øvrig har vi veldig gode muligheter for å kunne gjøre en god jobb. Med Norsk Elektronisk Legehåndbok (NEL) noen tastetrykk unna handler dette om å ta seg tid til å se etter om våre valg er i tråd med oppdatert kunnskap. Jeg opplever det som befriende at vi ikke taper ansikt når vi sjekker ut ting mens pasientene er til stede. De liker at jeg kontrollerer meg selv.

Stemmen er plutselig mindre positiv. 
- Apropos NEL, jeg må si at den manglende evnen man hadde i Helsebiblioteket til å se at dette var et godt hjelpemiddel for oss allmennleger, sier mye om den arrogansen man kan utvikle når det er lenge siden man selv har praktisert som lege.

Vi manøvrerer oss tilbake til temaet.

- Når man har gjort en feil, er den eneste farbare vei å legge seg flat, innrømme feilen og ikke prøve å dekke over noe. Det kan være tøft mens det står på, men ærlighet varer lengst, her som ellers i livet, slår Steven fast og fortsetter: - Dersom feilen ender som en klagesak, kommer man lengst med å forsøke å opprette dialog med den som har klaget. Jeg har erfart at det gode lege-pasient-forholdet kan gjenopprettes med slike samtaler. Det viktigste for en pasient som klager er at vedkommende blir hørt - og at vi innrømmer det når vi har tatt feil.

Det sies jo at hvis du ikke tåler tanken på å falle ned, skal du ikke gå på fjellet. Det er en god metafor for hva man må tåle hvis man vil være allmennlege. På mange måter var det enklere før, vi måtte ofte trå til uten tanke på å få assistanse fra ambulanse eller tilkalle helikopter.

Steven forteller om en pasient som hadde falt i en ståltrapp og nærmest var skalpert, blodet fosset. Det blåste orkan, fergene gikk ikke, strømmen hadde gått. Han måtte jobbe med ytterdøren åpen og bruke billyktene som lyskilde. Hemoglobinverdien falt fra $14 \mathrm{~g} / 100 \mathrm{ml}$ til $8 \mathrm{~g} / 100 \mathrm{ml}$ på ett døgn. - Senere fremsto pasienten som Olav den hellige med blå suturer over hele den blanke skallen, selv om håret hans sikkert var av en mykere variant, ler Steven.

- Ingen tenkte på om vi gjorde feil, vi gjorde bare jobben så godt vi kunne.

\section{Kollegial støtte}

Steven fremstår som en «reflektert survivor». Det har utvilsomt røynet på i perioder, men han synes å ha «stått han av» uten nevneverdige skrammer. Ikke alle klarer seg så godt i legelivet. Er ivaretakelsen av kolleger som sliter, for eksempel ved klagesaker, bra nok?

- Mange føler nok at de står alene. Vi som er kolleger, bør på en eller annen måte støtte dem som er ute i hardt vær. Om ikke annet bør vi ta kontakt og spørre om hvordan de har det. Et så enkelt spørsmål kan gjøre en stor forskjell for den som sliter.

Han forteller at han for noen år siden tok et slikt initiativ overfor en fullstendig ukjent kollega som var fengselslege i Tromsø og ble presset ut av stillingen sin med både fengselsvesenet og kommunen mot seg. - Jeg leste om saken på EYR (allmennlegenes debattforum på Internett) og tok kontakt med ham for å gi ham min støtte. Legeforeningen engasjerte seg ikke før legen fikk medhold i saken. Da ble jeg ble så provosert at jeg meldte meg ut. Jeg har ikke meldt meg inn igjen ennå. I stedet for å betale kontingent valgte jeg og en del kolleger å samle inn midler for å hjelpe legen med hans utlegg i saken.

Det komiske er at kona mi er tillitsvalgt for Legeforeningen her på øya, mens jeg altså har meldt meg ut i protest, sier han og

\section{«A dele humor skaper tillit mellom lege og pasient»}

ler litt oppgitt: - Jeg melder meg vel inn igjen med tid og stunder. Det er etter mitt syn viktig å være fagorganisert.

Steven Crozier har erfaring med å melde seg ut av Legeforeningen - $\mathrm{i}$ takstforhandlinger for en del år siden endte man opp med at legene fikk bedre betalt for å sitte på møter på dagtid enn å være oppe om natten og redde liv. - Det var så distriktsfiendtlig at jeg meldte meg ut i protest da også, sier han.

\section{Røyk og fedme}

Steven har jobbet mye med forebyggende medisin, og han har brukt atskillig tid på å prøve å få pasientene til å slutte å røyke.

- Det å ta en røykeanamnese kan virke provoserende på enkelte. Kanskje har jeg vært for ivrig, i alle fall tidligere. Det gikk rykter på øya om at jeg ikke ville hjelpe dem som ikke sluttet å røyke. Jeg husker godt en mann som takket for at jeg hadde spurt om han røykte. Han var blitt så provosert av spørsmålet at han sluttet i sinne! Jeg synes fortsatt jeg ikke har gjort jobben skikkelig hvis jeg ikke spør om røykevaner. Jeg velger å tro at slikt arbeide har gevinst på sikt, sier han.

- Fedme er et tema som kanskje er enda vanskeligere. Vi ser epidemien velte innover oss, men på dette området er skamfølelsen ofte så stor at det nærmest er umulig å ta det opp. Dersom pasienten spør om råd, prøver jeg å gjøre det veldig enkelt: Små, hyppige måltider og fysisk aktivitet som man liker. Jeg er tilbakeholden med å foreslå operative løsninger for fedme. Vi vet lite om langtidseffektene av inngrepene, andre ting bør være grundig utprøvd før vi henviser overvektige til gastrisk bypass.

\section{Fremtidens leger}

Rekruttering av unge leger har vært tema rundt lunsjbordet på legekontoret på Frøya utallige ganger. I de 28 årene Steven og kona har vært leger på øya, har kommunen ofte måttet ty til korttidsvikarer i ledige stillinger. Nå er alle stillingene besatt.

- Vi ser at flere av de unge nå velger å flytte hjem etter endt utdanning. Vi har nå en kollega som er oppvokst på Frøya, andre frøyværinger under utdanning sier de ønsker seg hit. En såkalt nullavtale, der vi slipper alt økonomisk og administrativt ansvar for legekontoret, gjør det lettere å få unge leger hit. Felles legevakt med nabokommunene er avgjørende for de unge. Det er en ordning som er kommet for å bli, selv om reiseveien til legevakten nattetid er lang for pasientene. Befolkningen er mer tjent med en fastlege som er der over tid enn å ha leger på vakt om natten. Ambulansetjenesten er nå godt utbygd, så de som blir syke, er ikke så avhengige av at vaktlegen er i nærheten.

\section{Nevrofeedback}

Steven tilbyr utvalgte pasienter trening med nevrofeedback. Den mest brukte metoden bygger på instrumentelt betinget læring, slik Pavlov viste i sine forsøk med hunder. Undervisning i dette blir gitt ved Norges teknisk-naturvitenskapelige universitet. En annen måte er LENS (low energy neuro stimulation) - der et modulert EEG sendes tilbake til pasientens hjerne. Én hypotese er at hjernen så autoreguleres ved å tilpasse timing, fase og amplitude i nevronensemblene på en mer hensiktsmessig måte. Det er slik musikere ved hjelp av monitorer tilpasser timing, toneleie og volum overfor medmusikantene. Man tenker seg at det er samme mekanisme som gjør at rolig musikk har beroligende virkning. Effekten av nevrofeedback er ikke testet dobbeltblindt og metoden må betraktes som eksperimentell, noe pasienten blir orientert om.

- Kanskje er det en ren placeboeffekt. Da er den i hvert fall formidabel, slik jeg ser det. Pasienter med tinnitus opplever at de får det bedre, migrenepasienter har sjeldnere og mildere anfall. Barn med AD/ HD der foreldrene ønsker et alternativ til sentralstimulerende medisiner trener nevrofeedback, og spedbarn med utpreget nattskrekk får også behandling.

Ikke alle de utenomfaglige interessene Steven dyrker, fikk plass i dette intervjuet. Vi rakk heller ikke å snakke om at han også har drevet med hypnose. For så vidt gjør ikke det så mye. Steven har planer å være fastlege på Frøya i mange år til. Skulle du treffe på ham en stormfull høstkveld, skal du vite at det verken skorter på talegaver eller samtaleemner. Sett av kvelden til en berikende samtale!

\section{Jannike Reymert}

jannike.reymert@ntebb.no

Bakklandet legekontor

Namsos 